\title{
Sranan Tongo Language
}

National Cancer Institute

\section{Source}

National Cancer Institute. Sranan Tongo Language. NCI Thesaurus. Code C154130.

An Eng lish-based creole spoken in Suriname. 